\title{
Exploring the multiple benefits of Ecosystem-based Adaptation in tourism for climate risks and destination well-being
}

\begin{abstract}
Tourism is strongly interlinked with the natural and social environment, in particular in destinations around the Pacific. These environments are vulnerable to climate change which impacts on the social-ecological system of destinations. Ecosystem-based Adaptation uses ecosystems to manage the risks of climate change. However, a gap remains in understanding how the tourism sector can use Ecosystem-based Adaptation to create destination-wide benefits. The Destination Ecosystem-based Adaptation Framework presented here aims to address this gap by focusing on well-being and climate risk reduction. The framework is applied to a Pacific case study site, Tanna island in Vanuatu, by drawing on primary qualitative data. Results highlight that Ecosystem-based Adaptation offers an approach for the tourism sector to create holistic benefits to destinations. Several constraints to successful implementation, and how these may be overcome, are identified. The paper contributes by providing a framework for other destinations which aim to create benefits through tourism.
\end{abstract}

Key Words: Ecosystem-based Adaptation, tourist destinations, climate change, well-being, social-ecological systems, Vanuatu, Tanna Island 


\section{INTRODUCTION}

Tourism is said to help meet the Sustainable Development Goals (SDGs), including action on climate. However, tourism's ability to deliver has increasingly been questioned (Becken, 2019; Hall, 2019). Tourism relies on, and interacts with, the natural environment including environmental attractions (e.g. pristine beaches, healthy coral reefs) (Buckely, 2008), resources (e.g. fresh water, food), and specific environmental conditions (e.g. waves for surfing, preferred weather) (Becken, 2013; Čavlek, Cooper, Krajinović, Srnec, \& Zaninović, 2018). The strong interconnectedness of tourism, host communities and the environment at the destination level is particularly prevalent in the case of many Pacific Small Island Developing States (SIDS) (Samoa Tourism Authority, 2012), partly because of social and cultural meanings attached to the environment (Movono, Dahles, \& Becken, 2017; Vanuatu National Statistics Office, 2012). It should hence be in the interest of tourism in these destinations to help maintain those ecosystem services on which the sector and communities depend on. Despite the clear link between island system health and tourism viability, a gap remains in understanding how the tourism sector can work with nature to manage change and, by doing so, create benefits to the wider destination (Mandić, 2019).

One driver of change that impacts upon SIDS destinations is climate change. The recently released Special Report on Global Warming of $1.5^{\circ} \mathrm{C}$ by the Intergovernmental Panel on Climate Change (IPCC) (2018) makes it very clear that climate change is happening rapidly and drastic action is required both to reduce carbon emissions and adapt to unavoidable impacts. To simultaneously achieve decarbonisation and adaptation considerable investment is necessary (World Bank, 2010). Given the resource constraints faced by SIDS, coupled with the high dependence on intact ecosystems, effective adaptation measures need to work with natural processes, rather than against them. Already, island ecosystems exhibit multiple mechanisms that naturally protect humans and their livelihoods. For example, coral 
reefs act as breeding ground for fish (livelihood) and they are important buffers to protect land against high seas and storms (Spalding, Ruffo, Lacambra, Meliane, Hale, Shepard, \& Beck, 2014). While building on these natural mechanisms should be at the core of successful destination adaptation initiatives, this opportunity has been widely overlooked in tourism studies.

Maintaining or enhancing ecosystem health is reflected in the concept Nature-based Solutions $(\mathrm{NbS})$. The benefits from working with the natural assets (including their constituent species) and processes that are already part of an ecosystem to generate a range of ancillary benefits and services is well recognised (Nesshöver et al., 2017). The International Union for Conservation of Nature (IUCN) (Cohen-Shacham, Walters, Janzen, \& Maginnis, 2016) has recognised a range of NbS concepts applying ecosystem-related approaches with the aim to address societal challenges. These include, amongst others, Ecological Restoration, Green Infrastructure, Ecosystem-based Disaster Risk Reduction and Ecosystem-based Adaptation. Ecosystem-based Adaptation ( $\mathrm{EbA})$ is a $\mathrm{NbS}$ to address climate change impacts (Cohen-Shacham et al., 2016) and has become a popular adaptation option with academics and practitioners, resulting in a growing body of knowledge on EbA (Doswald et al., 2014; Nalau, Becken, \& Mackey, 2018a). However, there remains a significant gap in the tourism context regarding both $\mathrm{NbS}$ generally and EbA specifically (Mandić, 2019). In particular, the question whether EbA could reduce climate risk and generate other flow-on effects, including benefits and trade-offs, to various destination elements has not been investigated. This study aims to address this gap through the following research question: How can the tourism sector utilise $\mathrm{EbA}$ in producing wider destination benefits?

To address this question, the paper first presents a review of relevant literature, and this is followed by the introduction of a framework for assessing holistic outcomes through 'Tourism and EbA'. This framework is then applied to a case study site in Vanuatu, to 
identify how the implementation of EbA in tourism is influencing a range of destination elements and what its opportunities are to enhance destination wide well-being. Finally, constraints that may be experienced by the tourism sector are discussed, and suggestions are made for how to address these.

\section{LITERATURE REVIEW}

The Need for a Holistic Approach to Adaptation in Island Tourism

Least Developed Countries (LDCs) and SIDS destinations are particularly vulnerable to climate hazards (UNFCCC, 2015): by creating risks to tourists, coastal tourism infrastructure and communities involved in tourism, as well as the natural environment destinations rely on. Despite those risks, Pacific SIDS and foreign investors continue to invest in tourism to meet development goals and spur economic growth (e.g. Ministry of Tourism, Industry, Commerce \& Ni-Vanuatu Business, 2013). This has two consequences: first, tourism itself may cause negative impacts on ecological components of destinations leading to ecosystem degradation (e.g. Gössling, 2001). Second, climate risk may undermine this new investment, jeopardising economic benefits for communities and the private sector.

Understanding that tourism activity is intricately interwoven with environmental and socio-cultural processes helps conceptualise a destination as a socio-ecological system (SES). The SES approach considers the human and environmental elements of destinations as one integrated system rather than separate entities (Heslinga, Groote, \& Vanclay, 2018). Science associated with SES encourages multi-disciplinary thinking as this provides a lens for investigating the key elements that link human and environmental system components (Cole \& Browne, 2015; Heslinga et al., 2018) and capturing the multiple interactions between them (Ostrom, 2007). This approach is especially useful when investigating how systems react to 
internal and external influences or challenges such as climate change (Baggio, 2014). In particular, it helps understand the intended and unintended knock-on effects that particular actions can produce. Systems thinking thus provides a suitable theoretical frame to guide this study.

Despite this opportunity, system thinking in the field of tourism and climate change remains limited. A growing body of literature on adaptation in tourism focuses on various aspects of business resilience, tourist behaviour, destination attractiveness and hazards (e.g. Becken, 2005; Čavlek et al., 2018; Jopp, DeLacy, Mair, \& Fluker, 2013; Mycoo, 2014; Scott, Simpson, \& Sim, 2012). Yet, there is a lack of existing tourism adaptation frameworks that are informed by systems theory (Loehr, 2020) and our systemtic understanding of the impacts of tourism adaptation on the wider destination, or vice versa, remains limited.

For tourism to be a vehicle for sustainable development, it is critical to find cost efficient, ecologically and socially viable adaptation strategies that enable the sector to function under changing climatic conditions (Morrison \& Pickering, 2013). Managing risk, reducing vulnerability and enhancing resilience all form part of a successful strategy that allow tourism destination systems to proactively adapt (Becken, 2013; Calgaro, Lloyd, \& Dominey-Howes, 2014). However, Hughey and Becken (2014) found that tourism operators commonly apply reactive coping strategies to deal with the impacts of climate change. Tourism needs to move towards applying anticipatory actions, which focus on long term changes and address the 'start-point vulnerability', which is made up of underlying economic, social, cultural, political and biophysical factors (Ensor \& Berger, 2009). A systems approach provides the platform based on which anticipatory adaptation can be examined, and driving forces for future climate risks be assessed. 
The Potential of Ecosystem-based Adaptation as a Nature-based Solution to Climate Change Impacts

$\mathrm{NbS}$ and EbA aim to address societal challenges by drawing upon the benefits derived from ecosystem services to the human population (Convention on Biological Diversity, 2009; Eggermont et al., 2015). This perspective aligns with systems thinking as it integrates outcomes for both environmental and human elements of SES (Nesshöver et al., 2017). Indeed, the term 'Nature-based Solutions' describes solutions that address climate change whilst also delivering biodiverdity and livelihood benefits (Eggermont et al., 2015). A debate persists as to whether $\mathrm{EbA}$ and $\mathrm{NbS}$ are synonyms or if the former has a meaning restricted to climate change (Cohen-Shacham et al., 2016). Nesshöver et al. (2017) argue that solutions that use nature processes and fail to consider EbA will not be climate proof. Clearly, there is a strong link between the two concepts and we continue this article by referring to EbA as a form of $\mathrm{NbS}$ focusing on climate change.

EbA is increasingly being recognised and integrated into global climate change policy, including the Paris Agreement (Nalau \& Becken, 2018). While EbA may not always be the most suitable adaptation option in all circumstances (Spalding et al., 2014), it is gaining popularity as an approach to adaptation in the Pacific (Nalau et al., 2018a, Nalau, Becken, Schliephack, Parsons, Brown, \& Mackey, 2018b). EbA, as "the sustainable management, conservation and restoration of ecosystems" (Brink et al. 2016, p. 113), offers a strategy that aims to strengthen ecosystems and livelihoods (Munroe et al., 2012) whilst also providing additional adaptation and risk management mechanisms for climate related hazards (Munang, Thiaw, Alverson, Mumba, Liu, \& Rivington, 2013). EbA therefore has the potential to address three key factors of climate risk: hazards, exposure and vulnerability (Oppenheimer, 2014). Due to its broad objectives, EbA secures ecosystem services, such as the quality of freshwater, food, soil fertility, shelter, inundation risk reduction and supply of 
other natural resources vital to life support in particular for people in poverty living in rural areas (Munang, Thia, \& Rivington, 2011). As such, EbA may not only contribute to climate risk reduction but more broadly to human well-being (Figure 1).

\section{[Insert Figure 1 here]}

EbA in Tourism and its Benefits

EbA has relevance for tourism as a number of tourism activities and coastal tourism infrastructure are ecosystem-based (Nalau \& Becken, 2018). However, while the climate change adaptation literature commonly links EbA with community-based adaptation (Reid, 2016) and broadly recognises the co-benefits EbA creates for tourism (e.g. Geneletti \& Zardo, 2016; Munang et al., 2013), tourism specific studies on EbA and NbS are lacking (Mandić, 2019). This could be due to the fact that EbA grew out of the context of conservation and natural resource management (Munroe et al., 2012), but not from tourism or business studies. Practically, tourism stakeholders may well have (unwittingly) implemented EbA activities without recognising them as such (Nalau \& Becken, 2018).

The relevant literature does provide insights into how EbA can benefit tourism (Supplement Table 1). Some measures, such as coral gardening or planting, are becoming quite common around the world, even though positive flow-on effects in terms of climate risk management benefits have only been recognised more recently. Capitalising on multiple benefits derived from EbA implemented by the tourism sector is therefore an important pathway to restore ecosystem health and destination well-being. Hereby destination wellbeing does not only refer to the subjective well-being of individuals, but encompasses 
intergenerational sustainable well-being (Smith, 2018) of all destination elements including the community and natural environment.

EbA as a Vehicle to Enhance Well-Being: Development of a Framework for Tourism

To test whether tourism may catalyse positive outcomes, the Destination Ecosystembased Adaptation Framework (DEAF) was developed (Figure 2). The framework is based on the theory of SES and the hypothesis that tourism stakeholders can implement EbA to generate multiple system benefits, including climate resilience and destination well-being. The framework builds on several existing frameworks: the conceptualisation of $\mathrm{NbS}$ and $\mathrm{EbA}$ introduced in Figure 1, which links climate change with well-being, and the IPCC risk assessment framework. To assess well-being, we draw on the OECD (2015) well-being framework and New Zealand Treasury Living Standards Framework, which state that future well-being "relies on the growth, distribution and sustainability" of four capitals: Natural capital; Social capital; Human capital; and Financial/ Physical capital (Smith, 2018, p. 4). All four categories are interlinked and supported by ecosystem services (Millennium Ecosystem Assessment, 2005), which suggests that they may be enhanced through EbA.

\section{[Insert Figure 2 here]}

It is not always straightforward to measure the stock and flow of the four capitals (Table 1), both in general and in specific destinations such as the Pacific. Linking the capitals and well-being approach to tourism indicates that tourism can not only profit from the four capitals, but more importantly, can be used as a tool to contribute and replenish them. While the four capitals and well-being may be defined differently in different countries (note, there 
are common denominators such as 'life satisfaction'), they provide broad categories that can be refined according to the specific environmental and cultural contexts.

[Insert Table 1 here]

\section{CASE STUDY CONTEXT AND METHODOLOGY}

This research assesses the potential of tourism EbA to increase benefits to the wider destination. It forms part of a larger project on $\mathrm{EbA}$ and climate risk reduction in Vanuatu (Mackey et al. 2017), including more work on the development of the destination SES, its variables, behaviour and feedback loops (Loehr, 2020). The following section sets out how the above DEAF was applied to Tanna island as a case study in Vanuatu.

Case Study Site - Tourism and EbA on Tanna

Tanna island, an emerging tourism destination (Nalau, Schliephack, \& Becken, 2017) is part of Vanuatu, a South West Pacific SIDS and LDC, and is one of six islands that make up Tafea Province, Vanuatu's southernmost province (Supplement Figure 1). Tourism is the leading economic sector nationally (Ministry of Tourism, Industry, Commerce \& Ni-Vanuatu Business, 2013), contributing a total of 46.1\% to GDP in 2017 (World Travel and Tourism Council, 2018). While Efate, the main island including the capital Port Vila, receive the majority of tourists (Vanuatu National Statistics Office, 2018), Vanuatu's tourism plan and infrastructure projects are aimed at spreading tourism benefits to less developed islands such as Tanna (Ministry of Tourism, Industry, Commerce \& Ni-Vanuatu Business, 2013). In 2018, Tanna received $33 \%$ of the visitors who travelled to outer islands (Vanuatu National Statistics 
Office, 2018). Tanna's tourism product is strongly based on traditional kastom culture as well as natural attractions and activities (Nalau et al., 2017).

Tanna island was damaged heavily by Cyclone Pam in 2015 (Deutsche Gesellschaft für Internationale Zusammenarbeit, 2017). Despite immense recovery processes and an improvement of roads, the level of infrastructure on Tanna remains low, and the majority of tourism businesses are small, and family or community operated. While the involvement in the cash economy is increasing, many people rely on traditional economic practices and natural resources for their livelihoods (Addinsall, Glencross, Rihai, Kalomor, Palmer, Nichols, \& Smith, 2016). The intimate relationship between ecosystems and local communities' livelihoods highlights the need to approach future developments or interventions holistically. Due to Vanuatu's high dependence on coral reefs, the World Resources Institute identified Vanuatu to be amongst the countries most vulnerable to coral loss and reef degradation (Burke, Reytar, Spalding, \& Perry, 2011). This explains why Tanna has previously been identified as a suitable site for EbA (Secretariat of the Pacific Regional Environment Programme, 2017).

Field Work and Data Analysis

An exploratory social science approach was applied to engage with a small but diverse number of stakeholders to better understand how EbA is used in tourism on Tanna and what benefits are created in form of flow-on effects through the destination SES. During field trips to Vanuatu in April and October 2018, 13 semi-structured interviews were conducted with tourism and climate change stakeholders on Tanna and at national level in Port Vila (Supplement Table 2). Individual semi-structured interviews are commonly used to explore new and complex topics (Jennings, 2010). Interviewees were first selected based on purposeful sampling whereby participants' knowledge and involvement in EbA and tourism 
was important. This was followed by snowball sampling where one interviewee recommended the next (Jennings, 2010). Aim was to include stakeholders representing the different elements of the SES. Interviewees included both $\mathrm{Ni}$-Vanuatu, the indigenous people of Vanuatu, and expatriates, people who have migrated to and permanently live and work in Vanuatu. The purpose was to collect in-depth insights into EbA based on participant's behaviour, experiences, perceptions and meanings (Hudons \& Ozanne, 1988; Liamputtong, 2013). Interviews commenced with questions on the interviewee's role, perceptions of climate risks to the destination, followed by questions on participant's experiences dealing with changes by applying EbA and ranged from 30-60 minutes.

In addition, two community group discussions were conducted (March 2017 and April 2018). These allowed participants to interact with each other and encouraged shy individuals (e.g. individuals who have not had much experience in participating in meetings with non Ni-Vanuatu researchers) to share their experiences (Liamputtong, 2013). One was held with a community on Tanna's West Coast in close proximity to some of the larger resorts and bungalows $(\mathrm{n}=17)$, and one with a remote community on the East Coast where tourism development is in an early stage $(n=16)$ (Supplement Figure 1). The discussions provided context in which participants' meaning was discussed and shared (Hudson \& Ozanne, 1988), including communities' use and reliance on local ecosystem services and their connections to tourism operations. The participation of diverse community representatives was important to capture the range of activities and viewpoints.

While interviews with tourism businesses and stakeholders were conducted in English, a local research assistant facilitated the community sessions in the local languages. All participants received information on the research project including the ethical conduct prior to the interviews. Interviewees provided written consent and individuals in community sessions provided oral consent due to low literacy skills as per the Griffith University Ethics 
approval number 2017/108. Since tourism and EbA is a new topic, interview questions were not deemed sensitive, thereby reducing the participant's feeling to provide 'socially acceptable answers'. Confidentiality and anonymity of individual participants was ensured to further reduce response bias and allow participants to speak more freely (Grimm, 2010). To ensure confidentiality, specific names of case study communities are not provided due to the small number of participants and tourism operations.

Interviews were recorded transcribed and analysed together with detailed notes taken during the community sessions. NVivo11 helped organise, code and categorise data (Saldana, 2016). Analysis commenced with a deductive or 'theoretical' thematic analysis (Braun \& Clarke, 2006) whereby the analysis was guided by previous knowledge, analytical interest and general systems theory. It therefore focused on the general elements of the SES first, before moving to the specifics (Elo \& Kyngäs, 2008). The first phase of coding relied on categories predetermined by the framework and literature, e.g. the four well-being categories and concept-driven codes (Gibbs, 2007). In NVivo, “nodes" were created for each code or category under which further child nodes were created. Nodes were merged, grouped, renamed or deleted as the analysis progressed. This process aided the second coding phase where further codes under each of the categories were identified in an inductive manner (data-driven codes) (Braun \& Clarke, 2006). For example, under the theme 'EbA outcomes for wellbeing, the code 'financial/physical capital' was created based on the framework. All data falling within this code were then further coded in an inductive manner to identify how the MPA is contributing to this type of capital. Child notes included, for example, 'income' and 'investment', with further child nodes that specified the type of 'investment'. Combining inductive and deductive coding acknowledges the influence of frameworks and the original research question, while also allowing new themes to emerge from the data (Fereday \& MuirCochrane, 2010). The writing of 'memos' throughout the initial coding phases allowed for 
analytical reflections of data and helped to further group and regroup codes to develop, name and define themes and sub-themes (Saldana, 2016; Braun \& Clarke, 2006). New themes emerged from the data such as constraints to implement EbA.

\section{FINDINGS}

\section{EbA on Tanna Island}

Communities on Tanna directly rely on ecosystem services including the provision of food, freshwater and natural building material. Similarly, tourism operators, who generate the majority of cash income for communities, rely on the natural beauty of the local land- and seascapes, especially the fringing coral reefs, white sand beaches, tropical forests, and the island's active volcano, to attract visitors. Thus, taking an ecosystem-based approach to climate change adaptation resonated naturally with stakeholders.

Participants were asked about their actions addressing climate risks and in particular whether they are applying initiatives that involve 'working with nature'. The dominant measure reported that could be labelled 'EbA' is to set up Marine Protected Areas (MPAs). There are currently two independent initiatives to create MPAs that are driven by tourism operators, or communities involved in tourism. On the east coast of Tanna, the development of a larger scale MPA that encompasses the reef of five Nakamals (communities) is underway. The main motivation here is to counteract some of the declines of the local marine environment the community is experiencing and to reduce community vulnerability to climate change. The implementation of this EbA is part of a wider Pacific Ecosystem-based Adaptation to Climate Change (PEBACC) program and therefore receives financial and logistical support and guidance in the implementation by the Secretariat of the Pacific 
Regional Environment Programme (SPREP). However, the local leadership and action stems from the owner of the adjacent bungalow operator (Operator 1) and his wider family.

The second MPA to be established is on the West Coast of the island. Tourism operators who are all part of the same local tourism association are in the process of establishing a MPA in front of their tourism businesses, whereas one of the resorts has been protecting its local reef for three years. In this case, the main motivation is conservation of the marine ecosystem for the benefits of tourism. Addressing climate risk is a currently unrecognised co-benefit.

EbA Benefits for Tanna as a Destination

Stakeholder engagement identified a range of opportunities in form of flow-on benefits that EbA strategies, such as MPAs supported by tourism, provide to the destination SES. Following the DEAF, these start with strengthening the ecosystem, replenishing the four capitals and decreasing climate risk by reducing exposure, emissions or vulnerability (Figure 3). The flow-on benefits created under each of the four capitals are explained in more detail below.

\section{[Insert Figure 3 here]}

\section{Natural Capital}

\section{Reduced risk from climate change}

Enhancing ecosystem health is one of the main aims of EbA. Healthy ecosystems are more resilient to shocks and stressors and therefore more likely to withstand climate change (Jones, 
Hole, \& Zavaleta, 2012). Operator 1 reported erosion in front of his property, and community members expressed concerns about the loss of land impacting the school property located on top of a cliff. Actively investing in maintaining a healthy and resilient reef could reduce the pressure of large swells on the coastline and avoid exacerbation of existing erosion. Notably, EbA approaches such as revegetation and coral gardening create carbon storage and sequestration opportunities (Jones et al., 2012) which contributing to global efforts to reducing carbon concentrations in the atmosphere.

\section{Biodiversity and natural attractiveness}

EbA such as implementing a MPA creates significant biodiversity and conservation opportunities (Figure 3). Tourism operators reported benefits of creating no-take zones. Operator 8, whose reef has been protected informally for three years, stated: "Yes, it works very well. Right now we've got a lot of shells that are coming back, [...] the lobsters are out there. The whales are coming in, you'll see a lot of fish. The best sign is shells coming back, you can see them. I've never seen some of the shells that I've seen here." Similarly, Operator 3 recalled the success of closing the reef for a period of six to eight months and reported regrowth and the return of shells and fish. In addition to enhancing biodiversity, this was recognised as flow-on benefits for tourism as the environmental quality and natural attractiveness increases.

\section{Social Capital}

\section{Valuing traditional knowledge and practices}

Initiating and supporting EbA projects can provide tourism operators with the opportunity to engage with the local community and their kastom practices. Protecting an area is a traditional kastom practice and not a foreign concept to communities. It is still common in many coastal communities around Tanna that a taboo is placed on fishing for a certain period 
of time, usually lasting between three and eight months. Furthermore, communities have a significant understanding and traditional knowledge of local ecosystems as Development Agency 1 noted: "And the traditional knowledge that exists down there is incredible as well. And people use that as part of their coping mechanisms and so with the taboo and all of that, a lot of that comes from traditional practice and not anything that the Fisheries Department has said you should do this." Traditional knowledge, where relevant to EbA, should be appropriately incorporated into tourism EbA projects to create community ownership. Tourism has the potential to erode traditional cultural practices as people move from a subsistence to a cash economy. However, investing into EbA approaches, especially when these are informed by traditional knowledge of the ecosystem (Nalau et al., 2018b), may provide a way to value and preserve some of this knowledge (Figure 3).

\section{Strengthen networks}

Investing in preserving those ecosystem services that both $\mathrm{Ni}$-Vanuatu and the tourism sector rely on may enhance the relationship of groups involved in the process. Successful community conservation projects have the opportunity to build trust and enhance linkages among the stakeholder groups involved (Berkes, 2007). Interviews highlighted that implementing an MPA involves a range of stakeholders. It requires cooperation between tourism operators, local Chiefs, community members and government representatives. Therefore, where tourism businesses are foreign-owned or managed, an appropriately designed process of setting up an MPA can strengthen the relationship between tourism businesses and the local community. Where tourism operations are community run, the EbA process provides an opportunity to engage with a larger number of residents from within the community. Neighbouring communities (or other external actors) may also be involved in the EbA. NGOs or other intergovernmental organisations may provide support and guidance, such as SPREP with the PEBACC program. 


\section{Human Capital}

Natural resource security \& employment

Communities rely on the reef as a source of protein: "We're the end of the food chain and yet we're destroying it. How stupid is that? We need it. Locals need it" (Operator 8). Adaptation actions which improve marine ecosystem health are likely to enhance food security for the local population and create further system flow-on effects. They attract tourists, which creates more business for operators, and this means employment and participation in the cash economy (e.g. to help pay for school fees and other services). Government 1 raised the point that small enterprises also benefit from securing food production, such as tourist restaurants. EbA may also enhance access to other natural resources such as ornamental resources or building material. Coconut shells and dried pandanus leaves are used to make products such as matts and jewellery sold to tourists to create a small income (Operator 6). Appropriate levels of tourism activity can help reduce poverty and increase people's adaptive capacity to deal with climate change, in particular for women.

\section{Education and capacity}

While communities in Vanuatu know and understand their land very well, they are often unsure how to deal with unprecedented climate changes that impact upon their natural system. Operator 1 explained: "There have been a lot of big questions around why this [climate change] is happening and because for the locals we don't really know and see why are the things [environmental changes] happen, which are the things that are causing all these problems." In addition, several interviewees explained that many community members do not think long term and struggle with concepts such as conservation. Hence the findings confirm a tendency to think short term which may influence people's adaptive capacity 
(Warrick, Aalbersberg, Dumaru, McNaught, \& Teperman, 2017) and tourism can play an important role by implementing long-term initiatives.

Knowledge and skills are also required to implement a MPA and ensuring it is managed not just for protection but also to increase resilience against future climate change. Processes involved to established a MPA were not always clear to tourism operators (Operator 3). Government agencies can provide support to operators, e.g. in terms of information on how to successfully implement EbA initiatives. The National Tourism Office is already providing information to operators on how to run a business, and the Vanuatu Skills Partnership has have a program on enhancing tourism business capacity around Tanna. There is hence an opportunity to build on existing networks and disseminate information on climate change adaptation. Tourism businesses also have a role to play as they can educate the local population on the importance of addressing climate change, e.g. through training staff and engaging with the community. Tourists themselves are already involved in EbA activities such as tree planting in other locations around Vanuatu (Government 2) and there may be an opportunity to involve tourists in coral restauration as an educational and nature experience.

Financial/ Physical Capital

\section{Funds for adaptation}

Tourism generates much needed income for community members and creates necessary funds that can be invested in implementing EbA initiatives, e.g. to protect infrastructure. Several interviewees, especially at national level, recognised the opportunity tourism provides to contribute to funding adaptation initiatives such as EbA: "I think tourism is essential, it's a main income earner, it gives money to invest in adaptation and then it helps 
the environment" (Development Agency 1). This also applies to the business ability to implement other adaptation and mitigation actions, such as investing in solar energy, which several operators mentioned. In addition to direct actions instigated at business level, there is an opportunity for national government to purposefully redirect a certain percentage of tax gained through tourism towards local level EbA.

Funds to improve and grow businesses

There is strong ambition from community operators to generate income to further invest in their business. Key investment areas relate to basic infrastructure and amenities such as sanitation facilities including septic tanks. This will enhance the quality of the natural environment, and increase the capacity to accommodate visitors. It also has positive effects for hygiene and basic needs (i.e. drinking water) of the local population. In addition, generating income creates the opportunity for accumulating savings. While a lot of operators around Tanna struggle to generate large savings, having savings proves crucial in a business recovery after an extreme event as Operator 4 stated: "It worked out. With the small money that we had at the bank, we managed to withdraw and we're still doing some maintenance after Cyclone Pam." At a larger scale, tourism is responsible for much of the direct investment into physical capital and it also indirectly influences investment into larger infrastructure upgrades such as road infrastructure, airport upgrades and community connection to the main electricity grid.

\section{Constraints for Tourism to Implement EbA}

A number of constraints were identified by participants that might hinder tourism operators in their successful implementation of EbA initiatives and their contribution to well-being (see Table 2). Several interviewees noted that climate change is not the only pressure the Tanna destination SES faces. Population growth causes an ever increasing need to extract resources 
and tourism itself adds pressure, e.g. in terms of waste creation which is a problem for rural communities due to a lack of recycling and proper waste management facilities on Tanna. In addition to growing population and visitor numbers, changes to demographics also add pressure to coastal areas. Interviewees recognised the increase in population along the coastal communities as resorts require more and more staff.

EbA projects need to involve the community; however, communal decision-making processes may require time and extensive consultation. Kastom cultural practices are still strong on Tanna which also influences decision making. Decisions are commonly made at community level meaning everyone has to agree. This becomes difficult if not everyone is convinced of the EbA initiative. According to Operator 3 this may be because: "It is a new thing for people, especially in Vanuatu, it's new so you have to go down, consult with the chiefs, the women, the communities, and the provinces too, just help them understand the climate change issues that will be affecting us." This highlights that traditional consultation and decision-making practices need to be respected and incorporated into planning for successful outcomes.

Conflicting interests of resources may also impact on EbA implementation. While EbA may provide tourism operators with an opportunity to engage communities and build on the traditional understanding of taboo areas, there are some kastom practices that can be counteractive to the implementation of EbA as Operator 4 explained: "Well, it was the kastom for years and years and years like at certain times of the year, people from Middlebush, can come down and go fishing and just basically eat turtles and do other things. But we want to prohibit this". Having access to certain marine species for food and kastom ceremonies is part of Ni-Vanuatu's cultural practices for which exception to conservation principles are made. Several interviewees also spoke about the fact that kastom practices are eroding and taboos, which are placed on reefs by the Chiefs, are increasingly being 
disrespected, e.g. by fishing at night. These circumstances highlight that the difficult tradeoffs involved in creating an MPA can lead to trust issues and may interfere with the conservation goals of tourism operators.

In some cases, usage rights were not clear and enforcement was lacking. Complains were expressed about reefs being closed for communities while the Chief's family continued to fish. Regulations in form of by-laws are required to identify the usage rights of the MPA which then need to be enforced; however, who will enforce these was unclear. Capacity of provincial governments are low and enforcing MPAs may not be of high priority. One operator made the protection of the reef part of his 75 year land purchasing agreement which he reported to be working well. However, this may not work in all cases.

Finally, while many participants recognised the importance of EbA to address climate change impacts, others, in particular expatriates, were focused on the conservation benefits an MPA provides for tourism. This may be due to the fact that expat interviewees were based at bigger resorts that house cyclone proof buildings and are less vulnerable. In addition, NiVanuatu operators tended to be more reliant on ecosystem services, such as food and freshwater for life support, and hence felt the impact of declining ecosystem health personally, the quality of the reef and availability of fish being an important factor. Operator 5 thought of introducing new species to the reef: "And we want to plant stuff like clam shells. So that you can have people snorkelling and seeing.", which suggests that operators are prepared to actively engage in reef restauration. However, these activities need to be implemented with climate resilience in mind and not just beautification for tourism.

\section{DISCUSSION}


This paper has examined the potential of $\mathrm{EbA}$, a form of $\mathrm{NbS}$ to specifically address climate change, for the tourism industry. Probably due to EbA being a new approach in a tourism context, despite the potential, tourism operators do not yet apply a wider range of EbA interventions on Tanna. By applying a SES lens, flow-on effects from MPAs as EbA were identified which create multiple benefits by building natural, social, human and financial/ physical capital and also contributing to reducing climate risk of the destination. Healthy ecosystems may provide these benefits not only during extreme events, they can grow stronger over time and provide the potential for self-recovery and incremental adaptation to climate change induced impacts (Sutton-Grier, Wowk, \& Bamford, 2015). Several constraints operators may encounter were identified. Table 2 presents an overview of how these may be addressed in order to maximise benefits created by EbA.

\section{[Insert Table 2 here]}

For EbA to be successful in increasing resilience and adaptive capacity and contributing to the four capitals, a holistic and proactive approach to reducing stress on ecosystems needs to be taken. Tourism can initiate and contribute to EbA by providing resources and building on capacity available in the sector. However, EbA needs to be supported by applying sustainable business practices more generally including mitigation actions to reduce pollution (Becken, 2005). This also applies to guests, staff and the community and tourism can play a role in educating and creating awareness. Studies on tourism and marine wildlife tours have shown that education can foster environmental attitudes and behaviour aiding conservation (e.g. Zeppel, 2008). Educating staff, community members and guests on appropriate behaviour does not only enhance knowledge and skills 
and therefore human capital, it can lead to a reduction in damage caused to ecosystems such as breaking off corals and pollution. The importance of education and awareness creation on sustainable behaviour is relevant to other forms of $\mathrm{NbS}$ implemented within tourism as it can help reduce tourism's impact on the natural environment these initiatives aim to strengthen.

Creating no take zones and restricting access to ecosystems can create conflict as it limits people's access to harvest. The issue of trade-offs has been identified more broadly in connection with $\mathrm{NbS}$ and natural resource management as the aim to generate wide-ranging benefits inherently involves larger numbers of stakeholders (Eggermont et al., 2015). For the initiative to be successful, trade-offs need to be reduced as much as possible (Andrade et al., 2011). Therefore, EbA initiatives need to involve engagement and discussions with the community to better understand expectations, synergies and trade-offs (Eggermont et al. 2015), e.g. on creating alternative sources of food. While tourism may provide communities with the necessary funds to source additional protein from other communities, the challenge will be to ensure that income is distributed throughout the community. To create broad buy-in and ownership, community consultations should include the views of all community groups including that of the most vulnerable (Nalau et al. 2018b). Women and young people commonly work in tourism businesses on Tanna, so there is a direct link to start engagement.

To ensure MPAs are not just labelled as EbA but serve as climate change responses, management of those areas need to go beyond nature conservation goals (Reid, 2016) and take an active approach to enhancing ecosystem health and resilience, making explicit the feedback loops between the ecosystem services generated and how these help address climate-related risks. E.g. an activity such as coral gardening for fringing reef restoration (Rinkevich, 2014) will not only enhance biodiversity but help maintain ecosystem health and the role it plays in absorbing wave energy during storm events, thereby reducing the risk of coastal inundation. Forward planning and consideration of future climatic conditions, 
however, is necessary to ensure the viability of EbA intervention in the future, as climate change will impact ecosystem composition, structure and function (Oppenheimer et al., 2014). MPAs that are being set up as EbA in other locations have involved the introduction of new, more climate resilient species (Crichton \& Esteban, 2017). While this idea is not new to operators on Tanna, species should be selected based on their resilience and ability to cope with current but also future anticipated climate change stressors (Rinkevich, 2014). This forward planning and consideration of future climatic conditions is relevant not just to MPAs and $\mathrm{EbA}$ but to all $\mathrm{NbS}$ to ensure their viability in the future, as climate change will impact ecosystems (Oppenheimer et al., 2014).

Furthermore, enhancing the design and management of MPA networks is important to enhance their resilience (Burke et al., 2011). MPAs should be placed in strategic zones to increase the extend and connectivity of the ecosystem (Jones et al. 2012), which means a range of zones allowing varied human use such as fishing and tourism could be created (see Castrejo' \& Charles (2013) for example from the Galapagos islands). Operators commonly want the area of reef right in front of their property protected but these may not necessarily be the best area for strict protection. Therefore, studies should be undertaken to identify zones most effective for conservation and more active restoration actions, which may or may not be open to recreational activities such as snorkelling depending on the nature of the reef, as well as zones that can be left for fishing. Zoning and scaling human interaction based on conservation value is a common tool in protected area management and relevant for other NbS applied in tourism (Mandić, 2019). Finally, ongoing monitoring is required of the effectiveness of EbA interventions which in the case of coral reef ecosystems should involve the monitoring and removing of predator species such as Crown of Thorn (Bos, Gumanao, Mueller, \& Saceda-Cardoza, 2013), which several tourism operators are already practicing, either by doing it themselves or by paying members of the community. 


\section{CONCLUSION}

This paper draws on general systems theory, climate risk assessment, and community wellbeing concepts, to develop the DEAF. The framework addressed an important gap by assessing $\mathrm{EbA}$ as an adaptation option for tourism, and identifying the conditions required to create destination-wide benefits and minimise trade-offs. Results show that if constraints identified in this study are addressed, EbA implemented through tourism has the potential to create multiple benefits for destinations. These include reduced climate change risk through enhanced ecosystem health but also an increase in natural, human, social and physical/financial capitals. The ultimate outcome is enhanced destination well-being. EbA thus provides the tourism industry with an anticipatory approach to deal with long term changes and high uncertainty. The study contributes to the theoretical understanding of tourism SES, in particular how the human and environmental elements of a destination link and influence system outcomes. Using systems thinking to test an adaptation option, and assessing outcomes based on the four-capitals framework, provides an alternative method that factors in key elements of the system. This approach is relevant to assessing other tourism practices, including other forms of adaptation measures.

The paper has practical implications in that it identifies potential constraints that might affect tourism's implementation of EbA, and how these may be overcome. Furthermore, the results provide an indication of what negative knock-on effects may be created if the destination fails to maintain ecosystem health. This information can aid destination decision makers in the selection and implementation of more holistic adaptation initiatives. 
As this study builds on primary data collected at a case study site, Tanna island, results presented here are context specific. This is a limitation of this study. However, other destinations can build on the principle learnings, such as the potential for EbA in tourism, and what needs to be considered when planning to implement EbA. There is need for further studies to assess other EbA options suitable for tourism and share learning from other destinations to enhance the prospect of EbA in tourism. This is important because if implemented now, EbA projects can influence future development in terms of land availability (e.g. if coastal zone is set aside for revegetation/protection), and leasing of land to new tourism development may be linked to criteria for the use of ecosystems such as the reef. This would enhance the destination system's resilience and capacity to adapt to future climate change impacts. 


\section{REFERENCES}

Addinsall, C., Glencross, K., Rihai, N., Kalomor, L., Palmer, G., Nichols, D., \& Smith, G. (2016). Enhancing agroforestry in Vanuatu: striking the balance between individual entrepreneurship and community development. Forests, Trees and Livelihoods, 25(1), 78-96. doi:10.1080/14728028.2015.1093434

Andrade, A., Cordoba, R., Dave, R., Girot, P., Herrera, F. B., Munroe, R., . . Vergara, W. (2011). Draft Principles and Guidelines for Integrating Ecosystem-Based Approaches to Adaptation in Project and Policy Design: A Discussion Document. Turrialba, Costa Rica: IUCN. Retrieved from:

https://www.iucn.org/sites/dev/files/eba_guidelines_2012_revised_ver_2b.pdf

Baggio, R. (2014). Complex tourism systems: a visibility graph approach. Kybernetes, 43(3/4), 445-461. doi:10.1108/K-12-2013-0266

Becken, S. (2005). Harmonising climate change adaptation and mitigation: The case of tourist resorts in Fiji. Global Environmental Change, 15(4), 381-393. doi:10.1016/j.gloenvcha.2005.08.001

Becken, S. (2013). Developing A Framework For Assessing Resilience Of Tourism SubSystems To Climatic Factors. Annals of Tourism Research, 43, 506-528. doi:10.1016/j.annals.2013.06.002

Becken, S. (2019). Decarbonising tourism - mission impossible? Accepted Tourism Recreation Research.

Berkes, F. (2007). Community-based conservation in a globalized world. Proceedings of the National Academy of Sciences, 104(39), 15188. doi:10.1073/pnas.0702098104

Bos, A.R., Gumanao, G.S., Mueller, B., \& Saceda-Cardoza, M.M.E. (2013). Management of crown-of-thorns sea star (Acanthaster planci L.) outbreaks: Removal success depends 
on reef topography and timing within the reproduction cycle. Ocean \& Coastal Management, 71, 116-122. doi:10.1016/j.ocecoaman.2012.09.011

Braun, V., \& Clarke, V. (2006). Using thematic analysis in psychology. Qualitative Research in Psychology, 3(2), 77-101. doi:10.1191/1478088706qp063oa

Brink, E., Aalders, T., Ádám, D., Feller, R., Henselek, Y., Hoffmann, A., . . Wamsler, C. (2016). Cascades of green: A review of ecosystem-based adaptation in urban areas. Global Environmental Change, 36, 111-123. doi:10.1016/j.gloenvcha.2015.11.003

Buckely, R. (2008). Tourism. In Lindernmayer, D., Dovers, S., Olson, H.M., \& Morton, S., (Eds), Ten Commitments: Reshaping the Lucky Country's Environment. Collingwood: CSIRO, 125-130.

Burke, L., Reytar, K., Spalding, M., \& Perry, A. (2011). Reefs at Risk Revisited. Washington, D.C: World Resources Institute, The Nature Conservancy, WorldFish Center, International Coral Reef Action Network, UNEP World Conservation Monitoring Centre and Global Coral Reef Monitoring Network.

Calgaro, E., Lloyd, K., \& Dominey-Howes, D. (2014). From vulnerability to transformation: a framework for assessing the vulnerability and resilience of tourism destinations. Journal of Sustainable Tourism, 22(3), 341-360. doi:10.1080/09669582.2013.826229

Castrejón, M., \& Charles, A. (2013). Improving fisheries co-management through ecosystembased spatial management: The Galapagos Marine Reserve. Marine Policy, 38, 235245. doi:https://doi.org/10.1016/j.marpol.2012.05.040

Čavlek, N., Cooper, C., Krajinović, V., Srnec, L., \& Zaninović, K. (2018). Destination Climate Adaptation. Journal of Hospitality \& Tourism Research, 1096348018793507. doi:10.1177/1096348018793507 
Cohen-Shacham, E., Walters, G., Janzen, C., \& Maginnis, S. (Eds.). (2016). Nature-based Solutions to address global societal challenges. Switzerland: IUCN. doi:10.2305/IUCN.CH.2016.13.en

Cole, S., \& Browne, M. (2015). Tourism and Water Inequity in Bali: A Social-Ecological Systems Analysis. Human Ecology, 43(3), 439-450. doi:10.1007/s10745-015-9739-z

Convention on Biological Diversity. (2009) Connecting biodiversity and climate change mitigation and adaptation: report of the second ad hoc technical expert group on biodiversity and climate change. Technical Series 41(126). Montreal: Secretariat of the Convention on Biological Diversity.

Crichton, R., \& Esteban, M. (2017). Limits to Coastal Adaptation in Samoa: Insights and Experiences. In W. Leal Filho \& J. Nalau (Eds.), Limits to Climate Change Adaptation (pp. 283-300). Springer International Publishing. doi:10.1007/978-3-319-64599-5

Deutsche Gesellschaft für Internationale Zusammenarbeit. (2017). Post-Pam: lessons learned for [German] development cooperation in Vanuatu and the Pacific. Bonn: GIZ.

Doswald, N., Munroe, R., Roe, D., Giuliani, A., Castelli, I., Stephens, J., . . Reid, H. (2014). Effectiveness of ecosystem-based approaches for adaptation: review of the evidencebase. Climate and Development, 6(2), 185-201. doi:10.1080/17565529.2013.867247

Eggermont, H., Balian, E., Azevedo, J. M. N., Beumer, V., Brodin, T., Claudet, J., . . Le Roux, X. (2015). Nature-based Solutions: New Influence for Environmental Management and Research in Europe. GAIA - Ecological Perspectives for Science and Society, 24(4), 243-248. doi:10.14512/gaia.24.4.9

Elo, S., \& Kyngäs, H. (2008). The qualitative content analysis process. Journal of Advanced Nursing, 62(1), 107-115. doi:10.1111/j.1365-2648.2007.04569.x 
Ensor, J. E., \& Berger, R. (2009). Understanding Climate Change Adaptation: Lessons from community-based approaches. Warwickshire, UK: Practical Action Publishing Ltd.

Fereday, J., \& Muir-Cochrane, E. (2010). Demonstrating rigor using thematic analysis: a hybrid approach of inductive and deductive coding and theme development. International Journal of Qualitative Methods, 80-92. https://doi.org/10.1177/160940690600500107

Geneletti, D., \& Zardo, L. (2016). Ecosystem-based adaptation in cities: An analysis of European urban climate adaptation plans. Land Use Policy, 50, 38-47. doi:10.1016/j.landusepol.2015.09.003

Gibbs, G. (2007). Analyzing qualitative data.London: Sage Publications.

Gössling, S. (2001). Tourism, economic transition and ecosystem degradation: Interacting processes in a Tanzanian coastal community. Tourism Geographies 3(4), 430-453. doi:10.1080/146166800110070504

Grimm, P. (2010). Social Desirability Bias. In Sheth J. \& M. Malhotra (Eds.), Wiley International Encyclopedia of Marketing. John Wiley \& Sons, Ltd.

Hall, C. M. (2019). Constructing sustainable tourism development: The 2030 agenda and the managerial ecology of sustainable tourism. Journal of Sustainable Tourism, 1-17. doi:10.1080/09669582.2018.1560456

Hambira, W. L., Saarinen, J., Manwa, H., \& Atlhopheng, J. R. (2013). Climate Change Adaptation Practices in Nature-Based Tourism in Maun in the Okavango Delta Area, Botswana: How Prepared are the Tourism Businesses? Tourism Review International, 17(1), 19-29. doi:10.3727/154427213X13649094288025 
Heslinga, J. H., Groote, P., \& Vanclay, F. (2018). Using a social-ecological systems perspective to understand tourism and landscape interactions in coastal areas. Journal of Tourism Futures, 3(1), 23-38. doi:doi:10.1108/JTF-10-2015-0047

Hughey, K. F. D., \& Becken, S. (2014). Understanding climate coping as a basis for strategic climate change adaptation - The case of Queenstown-Lake Wanaka, New Zealand. Global Environmental Change, 27, 168-179. doi:http://dx.doi.org/10.1016/j.gloenvcha.2014.03.004

Hudson, L. A., \& Ozanne, J. L. (1988). Alternative Ways of Seeking Knowledge in Consumer Research. Journal of Consumer Research, 14(4), 508-521. doi:10.1086/209132

Intergovernmental Panel on Climate Change. (2018). Summary for policymakers. In V. P. Masson-Delmotte, Zhai, H. O. Po€rtner, D. Roberts, J. Skea, P. R. Shukla, ... T. Waterfield (Eds.), Global Warming of 1.5 C. Geneva, Switzerland: World Meteorological Organization. Retrieved from https://www.ipcc.ch/sr15/chapter/summary-for- policy-makers/

Jennings, G. (2010). Tourism research (2nd ed.). Milton, Qld: John Wiley \& Sons.

Jones, H. P., Hole, D. G., \& Zavaleta, E. S. (2012). Harnessing nature to help people adapt to climate change. Nature Climate Change, 2(7), 504-509.

Jopp, R., DeLacy, T., Mair, J., \& Fluker, M. (2013). Using a Regional Tourism Adaptation Framework to Determine Climate Change Adaptation Options for Victoria's Surf Coast. Asia Pacific Journal of Tourism Research, 18(1-2), 144-164. doi:10.1080/10941665.2012.688515

Khan, A., \& Amelie, V. (2015). Assessing climate change readiness in Seychelles: implications for ecosystem-based adaptation mainstreaming and marine spatial 
planning. Regional Environmental Change, 15(4), 721-733.

doi:http://dx.doi.org/10.1007/s10113-014-0662-4

Liamputtong, P. (2010). Performing qualitative cross-cultural research. New York:

Cambridge University Press.

Loehr, J. (2020). The Vanuatu Tourism Adaptation System: a holistic approach to reducing climate risk. Journal of Sustainable Tourism, 28(4), 515-534. doi:10.1080/09669582.2019.1683185.

Mackey, B. Ware, D., Nalau, J., Sahin, O., Fleming, C.M., Smart, J. C. R., ... Buckwell, A. (2017) Vanuatu Ecosystem and Socio-economic Resilience Analysis and Mapping (ESRAM). Apia, Samoa: SPREP. ISBN 978-982-04-736-7.

Mandić, A. (2019). Nature-based solutions for sustainable tourism development in protected natural areas: a review. Environment Systems and Decisions. doi:10.1007/s10669-01909718-2

Millennium Ecosystem Assessment. (2005). Ecosystems and Human Well-Being: Current State and Trends. Washington, DC, USA: Island Press.

Ministry of Tourism, Industry, Commerce \& Ni-Vanuatu Business. (2013). Vanuatu Strategic Tourism Action Plan 2014-2018. Port Vila: Department of Tourism.

Moberg, F., \& Rönnbäck, P. (2003). Ecosystem services of the tropical seascape: interactions, substitutions and restoration. Ocean \& Coastal Management, 46(1), 27-46. doi:10.1016/S0964-5691(02)00119-9

Morrison, C., \& Pickering, C. (2013). Limits to Climate Change Adaptation: Case Study of the Australian Alps: Climate Change Adaptation in Australian Alps. Geographical Research, 51(1), 11-25. doi:10.1111/j.1745-5871.2012.00758.x 
Movono, A., Dahles, H., \& Becken, S. (2017). Fijian culture and the environment: a focus on the ecological and social interconnectedness of tourism development. Journal of Sustainable Tourism, 26(3), 451-469. doi:10.1080/09669582.2017.1359280

Munang, R., Thiaw, I., Alverson, K., Mumba, M., Liu, J., \& Rivington, M. (2013). Climate change and Ecosystem-based Adaptation: a new pragmatic approach to buffering climate change impacts. Current Opinion in Environmental Sustainability, 5(1), 67-71. doi:https://doi.org/10.1016/j.cosust.2012.12.001

Munang, R. T., Thiaw, I., \& Rivington, M. (2011). Ecosystem Management: Tomorrow's Approach to Enhancing Food Security under a Changing Climate. Sustainability, 3(7), 937-954. doi:http://dx.doi.org/10.3390/su3070937

Munroe, R., Roe, D., Doswald, N., Spencer, T., Möller, I., Vira, B., . . Stephens, J. (2012). Review of the evidence base for ecosystem-based approaches for adaptation to climate change. Environmental Evidence, 1(1), 13-13. doi:10.1186/2047-2382-1-13

Mycoo, M. (2014). Sustainable tourism, climate change and sea level rise adaptation policies in Barbados. Natural Resources Forum, 38(1), 47-57. doi:10.1111/1477-8947.12033

Nalau, J., \& Becken, S. (2018). Ecosystem-based Adaptation to Climate Change: Review of Concepts. Griffith Institute for Tourism Research report No 15. Queensland, Australia: Griffith University.

Nalau, J., Becken, S., \& Mackey, B. (2018a). Ecosystem-based Adaptation: A review of the constraints. Environmental Science \& Policy, 89, 357-364.

doi:https://doi.org/10.1016/j.envsci.2018.08.014

Nalau, J., Becken, S., Schliephack, J., Parsons, M., Brown, C., \& Mackey, B. (2018b). The Role of Indigenous and Traditional Knowledge in Ecosystem-Based Adaptation: A 
Review of the Literature and Case Studies from the Pacific Islands. Weather, Climate, and Society, 10(4), 851-865. doi:10.1175/WCAS-D-18-0032.1

Nalau, J., Schliephack, J., \& Becken, S. (2017). Sustainable tourism growth: Tanna Island, Vanuatu. In N. Scott (Ed.) Managing Growth and Sustainable Tourism Governance in Asia and the Pacific. Madrid: World Tourism Organisation (UNWTO) and Griffith University, pp. 118-126.

Naviti, W. \& Aston, J. (2000). Status of coral reef and reef fish resources in Vanuatu. The Regional Symposium on coral reefs in the Pacific. pp 351-367.

Nesshöver, C., Assmuth, T., Irvine, K. N., Rusch, G. M., Waylen, K. A., Delbaere, B., . . Wittmer, H. (2017). The science, policy and practice of nature-based solutions: An interdisciplinary perspective. Science of The Total Environment, 579, 1215-1227. doi:https://doi.org/10.1016/j.scitotenv.2016.11.106

OECD. (2015). How's Life? 2015: Measuring Well-being. Paris: OECD Publishing.

Oppenheimer, M., Campos, M., Warren, R., Birkmann, J., Luber, G., O’Neill, B., \& Takahashi, K. (2014). Emergent risks and key vulnerabilities. In C. B. Field, V. R. Barros, D. J. Dokken, K. J. Mach, M. D. Mastrandrea, T. E. Bilir, ...L. L. White (Eds.), Climate Change 2014: Impacts, Adaptation, and Vulnerability. Part A: Global and Sectoral Aspects. Contribution of Working Group II to the Fifth Assessment Report of the Intergovernmental Panel on Climate Change (pp. 1039-1099). Cambridge, United Kingdom and New York, NY, USA: Cambridge University Press.

Reid, H. (2016). Ecosystem- and community-based adaptation: learning from communitybased natural resource management. Climate and Development, 8(1), 4-9. doi:10.1080/17565529.2015.1034233 
Rinkevich, B. (2014). Rebuilding coral reefs: does active reef restoration lead to sustainable reefs? Current Opinion in Environmental Sustainability, 7, 28-36. doi:https://doi.org/10.1016/j.cosust.2013.11.018

Saldana, J. (2016). The Coding Manual for Qualitative Researchers (3rd ed.). London: Sage. Samoa Tourism Authority. (2012). National Tourism Climate Change Adaptation Strategy for Samoa 2012-2017. Apia: Samoa Tourism Authority.

Scott, D., \& McBoyle, G. (2007). Climate change adaption in the ski industry. Mitigation and Adaptation Strategies for Global Change, 12,1411-1431. doi:10.1007/s11027-006$9071-4$

Scott, D., Simpson, M. C., \& Sim, R. (2012). The vulnerability of Caribbean coastal tourism to scenarios of climate change related sea level rise. Journal of Sustainable Tourism, 20(6), 883-898. doi:10.1080/09669582.2012.699063

Secretariat of the Pacific Regional Environment Programme. (2017). Pacific Ecosystembased Adaptation to Climate Change (PEBACC). PEBACC Newsletter 3\&4. Suva: SPREP.

Smith, C. (2018). Treasury Living Standards Dashboard: Monitoring Intergenerational Wellbeing. Report for the Treasury Kaitohutohu Kaupapa Rawa. June, New Zealand: Kōtātā Insight.

Spalding, M. D., Ruffo, S., Lacambra, C., Meliane, I., Hale, L. Z., Shepard, C. C., \& Beck, M. W. (2014). The role of ecosystems in coastal protection: Adapting to climate change and coastal hazards. Ocean \& Coastal Management, 90, 50-57. doi:https://doi.org/10.1016/j.ocecoaman.2013.09.007

Sutton-Grier, A. E., Wowk, K., \& Bamford, H. (2015). Future of our coasts: The potential for natural and hybrid infrastructure to enhance the resilience of our coastal communities, 
economies and ecosystems. Environmental Science \& Policy, 51, 137-148.

doi:https://doi.org/10.1016/j.envsci.2015.04.006

UNFCCC. (2015). Paris Agreement. Paris: UNFCCC.

Vanuatu National Statistics Office. (2012). Alternative Indicators of Well-being for Melanesia. Vanuatu Pilot Study Report. Port Vila: Malvatumauri National Council of Chiefs.

Vanuatu National Statistics Office. (2018). Statistics Update: International Arrival Statistics: September 2018 Highlights. Port Vila: Vanuatu National Statistic Office.

Warrick, O., Aalbersberg, W., Dumaru, P., McNaught, R., \& Teperman, K. (2017). The 'Pacific Adaptive Capacity Analysis Framework': guiding the assessment of adaptive capacity in Pacific island communities. Regional Environmental Change, 17(4), 10391051. doi:10.1007/s10113-016-1036-X

World Bank. (2010). Economics of Adaptation on Climate Change-Synthesis Report. Washington DC: World Bank.

World Travel and Tourism Council. (2018). Travel \& Tourism Economic Impact 2017 Vanuatu. Report, March, World Travel and Tourism Council.

Zeppel, H. (2008). Education and Conservation Benefits of Marine Wildlife Tours: Developing Free-Choice Learning Experiences. The Journal of Environmental Education, 39(3), 3-17. doi:10.3200/JOEE.39.3.3-18 
Table 1. The four capitals, well-being dimensions and links to tourism.

\begin{tabular}{|c|c|c|}
\hline $\begin{array}{l}\text { Four } \\
\text { Capitals }\end{array}$ & $\begin{array}{l}\text { OECD \& New Zealand } \\
\text { Treasury }\end{array}$ & Key Links to Pacific Tourism \\
\hline $\begin{array}{l}\text { Natural } \\
\text { Capital }\end{array}$ & $\begin{array}{l}\text { - Land, soil, water, plants, animals, } \\
\text { - } \quad \text { Minerals and energy sources } \\
\text { - } \text { GHG emissions \& air pollution }\end{array}$ & $\begin{array}{l}\text { - Natural attractiveness, coral reefs, wetlands } \\
\text { - GHG emissions } \\
\text { - Preferred weather for tourism }\end{array}$ \\
\hline $\begin{array}{l}\text { Social } \\
\text { Capital }\end{array}$ & $\begin{array}{l}\text { - } \text { Norms \& values } \\
\text { - } \text { Law } \\
\text { - } \text { Cultural in identity } \\
\text { - Peoples links to community }\end{array}$ & $\begin{array}{l}\text { - Values of destination stakeholders, including } \\
\text { cultural values } \\
\text { - Culture as attraction } \\
\text { - Tourism policies and plans } \\
\text { - Traditional land management practices } \\
\text { - Social networks } \\
\text { - Social \& gender equality }\end{array}$ \\
\hline $\begin{array}{l}\text { Human } \\
\text { Capital }\end{array}$ & $\begin{array}{l}\text { - Peoples' skills \& knowledge } \\
\text { - Education } \\
\text { - Health } \\
\text { - Employment }\end{array}$ & $\begin{array}{l}\text { - Skilled workforce } \\
\text { - Human \& institutional capacity } \\
\text { - Traditional knowledge \& skills } \\
\text { - Employment in tourism } \\
\text { - Tourism as vehicle for poverty alleviation }\end{array}$ \\
\hline $\begin{array}{l}\text { Financial/ } \\
\text { Physical } \\
\text { Capital }\end{array}$ & $\begin{array}{ll}\text { - } & \text { Infrastructure } \\
\text { - } & \text { Income } \\
\text { - Investment into R\&D } \\
\text { - } & \text { Assets }\end{array}$ & $\begin{array}{l}\text { - Quality of infrastructure } \\
\text { - Tourism benefits } \\
\text { - Investment into R\&D } \\
\text { - Access to land } \\
\text { - Government resources } \\
\text { - Private capital \& investment }\end{array}$ \\
\hline
\end{tabular}


Table 2. Constraints implementing EbA in tourism and how they may be overcome (based on primary data and interpretation of literature).

\begin{tabular}{|c|c|c|}
\hline Constraints & & How to overcome constraints \\
\hline $\begin{array}{l}\text { Destinations face a } \\
\text { range of pressures } \\
\text { besides climate } \\
\text { change }\end{array}$ & $\begin{array}{l}\text { - Population growth } \\
\text { - Tourism growth } \\
\text { - Growing populations in } \\
\text { coastal tourist destinations }\end{array}$ & $\begin{array}{l}\text { Holistic approaches that support EbA: } \\
\text { - Sustainable business practices } \\
\text { - Pollution reduction } \\
\text { - Education and awareness }\end{array}$ \\
\hline $\begin{array}{l}\text { Community decision } \\
\text { making and } \\
\text { consensus }\end{array}$ & $\begin{array}{l}\text { - Not everyone may agree } \\
\text { - Time consuming }\end{array}$ & $\begin{array}{l}\text { Traditional consultation and decision } \\
\text { making practices need to be respected and } \\
\text { time invested }\end{array}$ \\
\hline Conflicting interests & $\begin{array}{l}\text { - Differing priorities between } \\
\text { conservation and taking } \\
\text { marine life for kastom } \\
\text { ceremonies } \\
\text { - Disrespecting taboos }\end{array}$ & $\begin{array}{l}\text { - } \text { Provide alternatives } \\
\text { - Communication } \\
\text { - Community consultation and involvement } \\
\text { in projects }\end{array}$ \\
\hline Enforcement & $\begin{array}{l}\text { - Often no clear usage } \\
\text { regulations (by laws) } \\
\text { - Lack of enforcement due to } \\
\text { limited resources }\end{array}$ & $\begin{array}{l}\text { - } \text { Community buy-in } \\
\text { - Community ownership of MPA } \\
\text { - Enhance networks and cooperation } \\
\text { between operators and community }\end{array}$ \\
\hline $\begin{array}{l}\text { Difference between } \\
\text { conservation and } \\
\text { EbA }\end{array}$ & $\begin{array}{l}\text { - Varying expectations of } \\
\text { MPAs (conservation for } \\
\text { tourism benefits vs. climate } \\
\text { resilience) }\end{array}$ & $\begin{array}{l}\text { - } \\
\text { Education } \\
\text { Involve tourism operators and tourists in } \\
\text { reef restoration }\end{array}$ \\
\hline
\end{tabular}




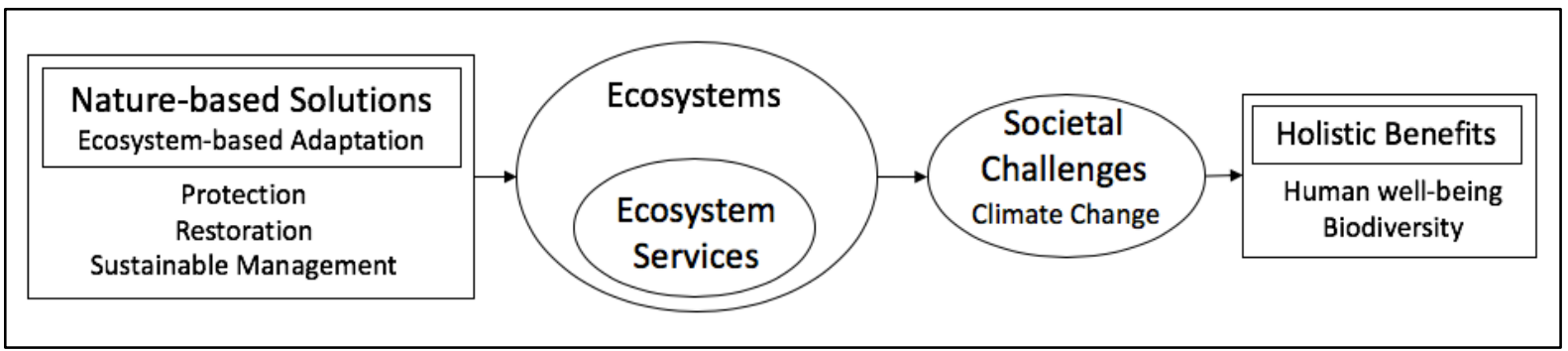

Figure 1. Ecosystem-based Adaptation as $\mathrm{NbS}$ to address climate change and create well-being (Source: adapted from IUCN NbS framework (Cohen-Shacham et al., 2016)). 
Online Supplement - Exploring the multiple benefits of Ecosystem-based Adaptation in tourism for climate risks and destination well-being

Supplement Table 1. EbA initiatives studied or reported in relation to tourism.

\begin{tabular}{|c|c|c|c|c|}
\hline $\begin{array}{l}\text { EbA } \\
\text { approach }\end{array}$ & Benefits to tourism & Other benefits & Location & Source \\
\hline $\begin{array}{l}\text { Planting of } \\
\text { trees, } \\
\text { reforestation }\end{array}$ & $\begin{array}{l}\text { Reduces vulnerability } \\
\text { to cyclones, enhance } \\
\text { microclimates, enhance } \\
\text { tourism landscape. } \\
\text { At resort scale, trees } \\
\text { provide shade and } \\
\text { thermal comfort and } \\
\text { enhance amenity value }\end{array}$ & $\begin{array}{l}\text { Trees serve as carbon } \\
\text { sinks, benefits } \\
\text { biodiversity, water } \\
\text { management, and soils }\end{array}$ & $\begin{array}{l}\text { Samoa, Fiji, } \\
\text { Botswana }\end{array}$ & $\begin{array}{l}\text { Becken, 2005; } \\
\text { Hambira, } \\
\text { Saarinen, } \\
\text { Manwa, \& } \\
\text { Atlhopheng, } \\
\text { 2013; Nalau } \\
\text { \& Becken, } \\
2018\end{array}$ \\
\hline $\begin{array}{l}\text { Coastal } \\
\text { revegetation } \\
\text { (non-tree } \\
\text { species) }\end{array}$ & $\begin{array}{l}\text { Helps trap sand, may } \\
\text { enhance appearance of } \\
\text { coastal sites }\end{array}$ & Stabilise the beach/soil & Samoa & $\begin{array}{l}\text { Crichton \& } \\
\text { Esteban, } 2017\end{array}$ \\
\hline $\begin{array}{l}\text { Coral } \\
\text { planting/ } \\
\text { transplantation }\end{array}$ & $\begin{array}{l}\text { Conserves natural } \\
\text { tourism assets }\end{array}$ & $\begin{array}{l}\text { Address reef damage } \\
\text { and coastal erosion } \\
\text { caused by sea level } \\
\text { rise and storm surges }\end{array}$ & $\begin{array}{l}\text { Samoa, } \\
\text { Barbados, } \\
\text { Bahamas }\end{array}$ & $\begin{array}{l}\text { Mycoo 2014; } \\
\text { Crichton \& } \\
\text { Esteban, } 2017\end{array}$ \\
\hline $\begin{array}{l}\text { Marine/reef } \\
\text { protection and } \\
\text { conservation }\end{array}$ & $\begin{array}{l}\text { Protects tourism's } \\
\text { resource base (to create } \\
\text { earnings) }\end{array}$ & $\begin{array}{l}\text { Helps restore degraded } \\
\text { reefs and lagoons, } \\
\text { protects/ enhances } \\
\text { marine biodiversity }\end{array}$ & Samoa, Fiji & $\begin{array}{l}\text { Becken, 2005; } \\
\text { Crichton \& } \\
\text { Esteban, } 2017\end{array}$ \\
\hline $\begin{array}{l}\text { Wetland } \\
\text { rehabilitation }\end{array}$ & $\begin{array}{l}\text { Provides coastal buffer } \\
\text { and defence }\end{array}$ & $\begin{array}{l}\text { Promotes conservation } \\
\text { of biodiversity, } \\
\text { opportunity for } \\
\text { education/ awareness, } \\
\text { freshwater diversion }\end{array}$ & Seychelles & $\begin{array}{l}\text { Khan \& } \\
\text { Amelie } 2015\end{array}$ \\
\hline $\begin{array}{l}\text { Planting/ } \\
\text { protecting } \\
\text { mangroves }\end{array}$ & $\begin{array}{l}\text { Enhances shoreline } \\
\text { stabilisation, } \\
\text { opportunities for } \\
\text { tourism }\end{array}$ & $\begin{array}{l}\text { Provides nursery } \\
\text { habitat for aquatic } \\
\text { organisms, source of } \\
\text { timber and fuel wood }\end{array}$ & Fiji, Samoa & $\begin{array}{l}\text { Becken, 2005; } \\
\text { Moberg \& } \\
\text { Rönnbäck, } \\
2003\end{array}$ \\
\hline $\begin{array}{l}\text { Snow Farming } \\
\text { (Strategic } \\
\text { planting or } \\
\text { retention of } \\
\text { trees) }\end{array}$ & $\begin{array}{l}\text { Trees capture snow and } \\
\text { provide shade on ski } \\
\text { slopes which reduces } \\
\text { snow melting }\end{array}$ & $\begin{array}{l}\text { Reduces snow making } \\
\text { requirements and } \\
\text { resource requirements } \\
\text { of ski fields }\end{array}$ & Canada & $\begin{array}{l}\text { Scott \& } \\
\text { McBoyle, } \\
2007 .\end{array}$ \\
\hline
\end{tabular}


Supplement Table 2. Stakeholder interviewed and interviewee codes.

\begin{tabular}{l|l|l|l}
\hline No & Stakeholder type & Location & Interviewee code \\
\hline 1 & Energy Consultant & Port Vila & Consultant 1 \\
\hline 2 & Tourism Operator (Ni-Vanuatu) & Tanna & Operator 1 \\
\hline 3 & Tourism Operator (Expat) & Tanna & Operator 2 \\
\hline 4 & Tourism Operator (Expat) & Tanna & Operator 3 \\
\hline 5 & Tourism Operator (Ni-Vanuatu) & Tanna & Operator 4 \\
\hline 6 & Tourism Operator (Ni-Vanuatu) & Tanna & Operator 5 \\
\hline 7 & Tourism Opeartor (Ni-Vanuatu) & Tanna & Operator 6 \\
\hline 8 & Tourism Operator (Ni-Vanuatu) & Tanna & Operator 7 \\
\hline 9 & Tourism Operator (Expat) & Tanna & Operator 8 \\
\hline 10 & Government (Ministry Climate Change) & Port Vila & Government 1 \\
\hline 11 & Government (Department of Tourism) & Port Vila & Government 2 \\
\hline 12 & Provincial Government & Tanna & Government 3 \\
\hline 13 & Development Agency (GIZ) & Port Vila & Development Agency 1 \\
\hline
\end{tabular}




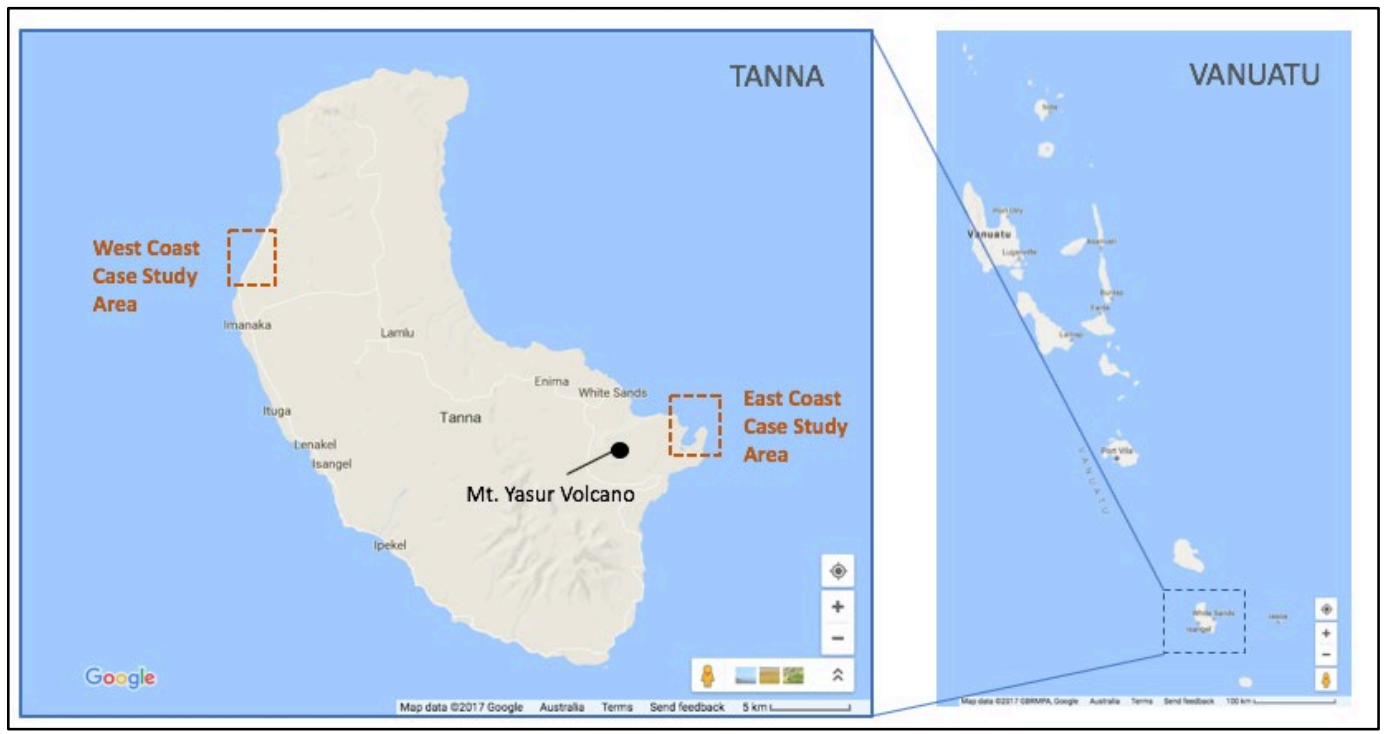

Supplement Figure 1. Case Studies sites on Tanna, Vanuatu (Source: amended from Google Maps). 


\begin{tabular}{|c|c|c|c|}
\hline NBS APPROACH & CAPITALS & SOCIETAL CHALLENGE & OUTCOME \\
\hline $\begin{array}{c}\text { Ecosystem-based } \\
\text { Adaptation } \\
\text { through Tourism }\end{array}$ & $\begin{array}{l}\text { Natural Capital } \\
\text { Social Capital } \\
\text { Human Capital } \\
\text { Financial Capital }\end{array}$ & $\begin{array}{l}\text { Climate Change Risk } \\
\text { - Vulnerability } \\
\text { - Exposure } \\
\text { - Hazard }\end{array}$ & $\begin{array}{c}\text { Destination } \\
\text { Wellbeing }\end{array}$ \\
\hline
\end{tabular}

Figure 2. The Destination Ecosystem-based Adaptation Framework (DEAF) (Source: informed by IUCN NbS framework, OECD well-being framework and IPCC Risk Assessment framework). 


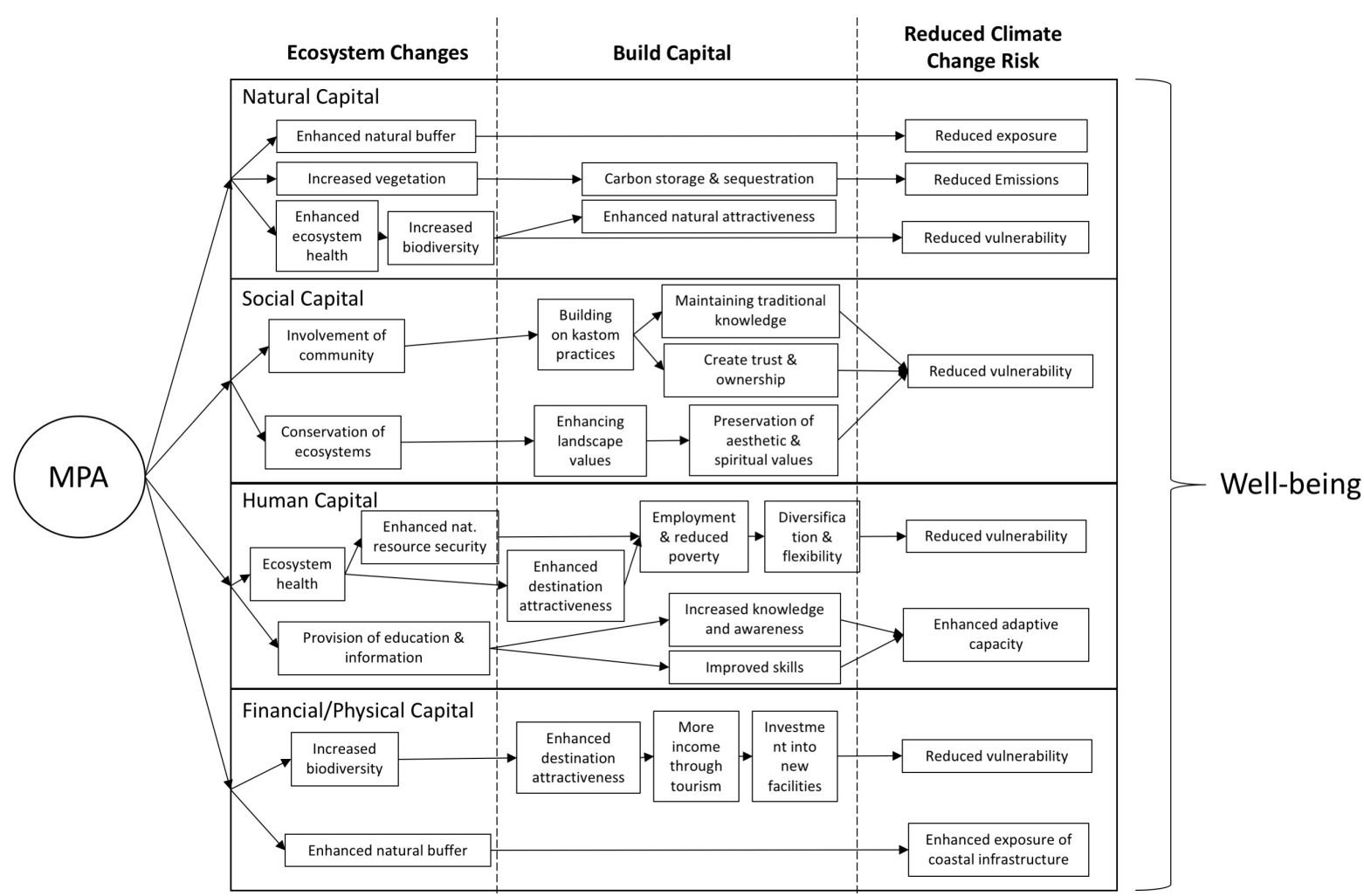

Figure 3. Flow-on benefits in the destination SES. Created through tourism instigated MPAs on Tanna, based on the DEAF. 